
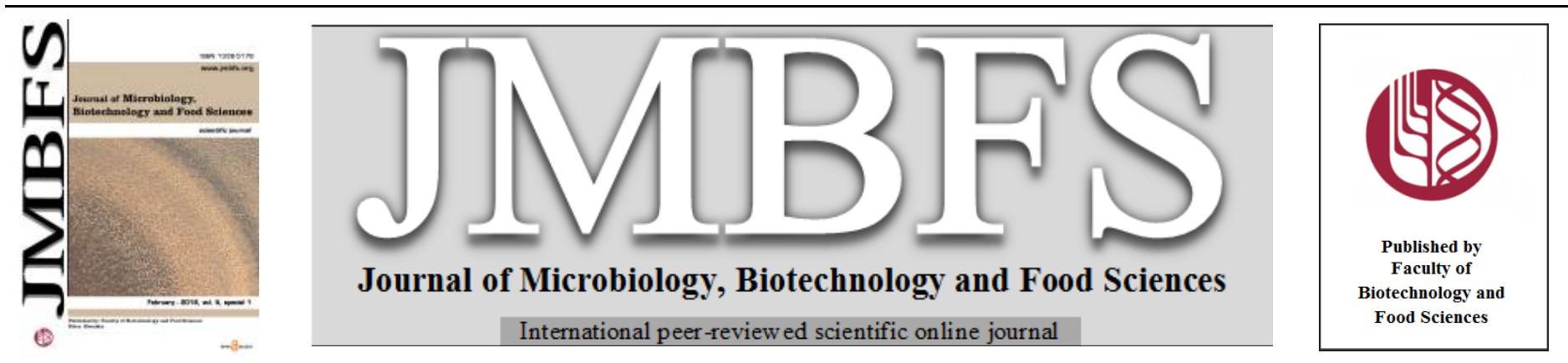

\title{
THE EFFECT OF THERMAL PROCESSING ON THE CONTENT OF BIOACTIVE COMPOUNDS IN CRANBERRY(Vaccinum macrocarpon) FRUITS
}

\author{
Małgorzata Dżugan, Katarzyna Rut, Monika Wesołowska
}

$\operatorname{Address(es):~}$

University of Rzeszów, Faculty of Biology and Agriculture, Department of Chemistry and Food Toxicology, 1 Ćwiklińskiej St., 35-601 Rzeszów, Poland, (17) 8721619.

*Corresponding author: mdzugan@ur.edu.pl

doi: 10.15414/jmbfs.2016.5.special1.36-39

\section{ARTICLE INFO}

Received 23. 12. 2015

Revised 22. 1. 2016

Accepted 28. 1. 2016

Published 8. 2. 2016

Regular article OPEN $\partial_{\text {ACCESS }}$

\begin{abstract}
Cranberries fruits like other fresh products lose their basic in particular bioactive components with the course of time and therefore there is a need of their immediate fixation. Drying and freezing are the most commonly used methods of extending the shelf life in the processing of these fruits. The aim of the study was to investigate the effect of thermal processing on the content of biologically active compounds in cranberry (Vaccinium macrocarpon) fruits. Samples of fresh fruits were frozen $\left(-20^{\circ} \mathrm{C}\right)$ and dried in various temperature condition $\left(59\right.$ and $\left.65^{\circ} \mathrm{C}\right)$. Moreover, for comparison market cranberry was used. In the fresh and processed samples of cranberry, the content of vitamin C (Tillmans), total phenolic compounds (Folin-Ciocalteau) and antioxidant activity (FRAP) as well as titratable acidity and anthocyanins were determined. Fresh fruits were characterized by the highest level of all tested parameters. Freezing causes the least possible loss of valuable ingredients. Significant losses of biologically active components in convective dried fruits were temperature-dependent but they were more abundant in antioxidant components than sweetened dried cranberry available in market.
\end{abstract}

Keywords: Cranberry fruits, thermal processing, bioactive components, antioxidants

\section{INTRODUCTION}

The American cranberry (Vaccinium macrocarpon Ait.), with an attractive bright red appearance and distinctive flavor, is recognized as a concentrated source of dietary flavonoids, including anthocyanins, flavonol glycosides, and proanthocyanidins (condensed tannins) as well as various phenolic acids (Caillet et al., 2011; Blumberg et al., 2013). This plant has been known and cultivated for a long time and in comparison to other, its fruits are highly appreciated by the people. Their special benefits come from many health-promoting properties which include antimicrobial (Lacombe et al., 2010; Côté et al., 2011), antifungal (Mckenna et al., 2002), anti-inflammatory, antioxidant (Sun et al., 2002), antiproliferative (Seeram et al., 2004), antiedema, diuretic, antipyretic (Blumberg et al., 2013).

Quercetin, possibly the most powerful phytonutrient of the cranberry, has been reported to be a growth inhibitor of primary bladder transitional cell cancers in humans (Lavigne et al., 2007; Pappas and Schaich, 2009; Gryszczyńska, 2010). These benefits appear to be principally due to the ability of cranberries to interfere with the adhesion of some bacteria to select cell types and surfaces, i.e. P-fimbriated Escherichia coli from adhering to uroepithelial cells, Helicobacter pylori, the causative agent of most gastric and duodenal ulcers, to gastrointestinal mucosa, as well as oral pathogens such as Streptococcus mutans to tooth hydroxyapatite (Lacombe et al., 2010; Côté et al., 2011). Recently, research on the effects of cranberries and their components has also been focused on their use in the prevention and treatment of cardiovascular disease(CVD) (McKay and Blumberg, 2007; Dohadwala et al., 2011).

Due to the presence of benzoic and citric acids, cranberry belongs to the fruit of high durability, but with additional fusing process (drying, freezing, candying) the period of its shelf life can be more extended (Blumberg $\boldsymbol{e t}$ al., 2013). Moreover, fresh cranberries fruits has pungent taste, which is not desirable by consumers, therefore different processing methods lead to increasing their eligible (Pappas and Schaich, 2009). Cranberries can be processed into fresh fruit concentrate, sauce products, and juice drinks. The single-strength juice is very acidic (pH 2.5) and unpalatable. So that, since 1930, cranberry juice cocktail, comprising a mixture of cranberry juice (33\%), sweetener, water, and added vitamin C, was introduced. Dried cranberry powder formulated in capsules or tablets is also available (Dorofejeva et al., 2011).

The aim of the study was to investigate the effect of drying and freezing process on the chemical composition of cranberry fruits available on the Polish market.

\section{MATERIAL AND METHODS}

\section{Material}

The material consisted of fresh garden cranberry (Vaccinum macrocarpon var Pilgrim) purchased in the shop. Fruits were frozen and dried to a constant weight (Table 1). As a control, sample of fresh cranberry fruits stored in refrigerators conditions were used.

Table 1 Characteristics of the sample preparation

\begin{tabular}{lccc}
\hline sample & temperature & time & used equipment \\
\hline fresh & $4^{\circ} \mathrm{C}$ & 7 days & refrigerator \\
frozen & $-20^{\circ} \mathrm{C}$ & 7 days & freezer \\
I dried & $59^{\circ} \mathrm{C}$ & $144 \mathrm{~h}$ & home fruit dryer \\
II dried & $65^{\circ} \mathrm{C}$ & $102 \mathrm{~h}$ & laboratory dryer \\
\hline
\end{tabular}

For comparison sweetened dried cranberries (composed of $70 \%$ dried fruits, $29 \%$ sugar and $1 \%$ sunflower oil; with calorific value $294 \mathrm{kcal}$ per $100 \mathrm{~g}$ ) available in local market were used.

\section{Methods}

Determination were made for fresh and processed samples of cranberry fruits. All assays were performed in three independent repetitions.

\section{The content of vitamin C according to Tillmans}

$10 \mathrm{~g}$ of crushed fresh and frozen cranberry fruits as well as dried samples (converted into fresh weight - FW) were extracted with $50 \mathrm{~mL}$ of $2 \%$ oxalic acid solution. The resulting mixture was left in the dark for 10 minutes and then filtered. $10 \mathrm{~mL}$ of the filtrate was titrated with a solution of 2,6dichlorophenolindophenol (DCPIP) until a light pink color. The content of vitamin $\mathrm{C}$ was given in mg per $100 \mathrm{~g}$ dry weight (DW). 


\section{Cranberry extract preparation}

For the other determinations cranberry extracts $(10 \% \mathrm{w} / \mathrm{v})$ were used. Cranberry samples ( $2 \mathrm{~g}$ of fresh and frozen and converted into FW amounts of dried cranberries samples) were dipped in $20 \mathrm{~mL}$ of distilled water. The obtained solutions were stirred for $20 \mathrm{~h}$ at room temeperature using a shaker and then filtered through syringe filter with a diameter of $0.2 \mu \mathrm{m}$.

\section{Anthocyanins}

The content of anthocyanins was determined spectrophotometricaly at various $\mathrm{pH}$ (AOAC Method 2005; Kaniewska et al., 2013). The determination principle consists in measurement the difference in absorbance at $\mathrm{pH}=1$ and $\mathrm{pH}=4.5$ at the wavelength $\lambda=510 \mathrm{~nm}$ and $\lambda=800 \mathrm{~nm}$. Anthocyanins at $\mathrm{pH}=1$ exist in the form of red flavylium cation, and at $\mathrm{pH} 4.5$ are converted into the form of a colorless pseudo-alkali. As a blank distilled water was used. The content of anthocyanins was calculated by special formula and expressed as \% of DW based on cyanidin-3-glucoside (main anthocyanin component of cranberry).

\section{Total content of phenolic compounds (Folin-Ciocalteau)}

To $100 \mu \mathrm{L}$ of obtained extracts, $500 \mu \mathrm{L}$ of Folin-Ciocalteau reagent (Merck, Germany; diluted in the volume ratio 1:10 with distilled water) and $400 \mu \mathrm{L}$ of $7.5 \% \mathrm{Na}_{2} \mathrm{CO}_{3}$ were added. The resulting solutions were allowed to stand for 90 minutes at room temperature and then the absorbance at the wavelength $\lambda=760$ $\mathrm{nm}$ were measured according to the blank. The content of phenolic compounds were calculated using the prepared calibration curve and expressed in mg gallic acid (GAE)/100 g DW (Piljac-Žegarac et al., 2009).

\section{Antioxidant activity (FRAP)}

The FRAP reagent contained $10 \mathrm{mM}$ TPTZ (Sigma, USA) solution in $40 \mathrm{mM}$ $\mathrm{HCl}, 20 \mathrm{mM} \mathrm{FeCl}$ and $0.3 \mathrm{M}$ acetate buffer $\mathrm{pH} 3.6$ (POCh, Poland), in volume ratio 1:1:10 (Çelik et al., 2008). Aliquots of $200 \mu \mathrm{L}$ of cranberry extracts $(0.1 \mathrm{~g}$ $\mathrm{FW} / 1 \mathrm{~mL}$ ) were mixed with $1.8 \mathrm{~mL}$ of FRAP reagent and the absorbance of the reaction mixture was measured spectrophotometrically at $\lambda=593 \mathrm{~nm}$ after incubation at $37^{\circ} \mathrm{C}$ for $10 \mathrm{~min}$ against blank. $1 \mathrm{mM}$ Trolox (Sigma-Aldrich, USA) was used for the calibration curves and the results were expressed as $\mathrm{mM}$ of Trolox equivalent (TE) per $100 \mathrm{~g}$ of fruits (DW).

\section{Acidity}

Five grams of the shredded fresh, frozen and dried cranberries samples (converted into fresh weight amounts) were heated to boil with $20 \mathrm{~mL}$ of water. The whole material was transferred to volumetric flask and made up to $50 \mathrm{~mL}$ with distilled water. After $15 \mathrm{~min}$ solution was filtered and $10 \mathrm{~mL}$ of the filtrate was titrated with $0.1 \mathrm{M} \mathrm{NaOH}$ to $\mathrm{pH}=8$ (measured by $\mathrm{pH}$-meter). Results were calculated for citric acid and showed as $\mathrm{g} / 100 \mathrm{~g}$ of DW.

\section{Statistical analysis}

Statistical calculations were performed using StatSoft Statistica, 9.0. Pearson's correlation coefficients to assess interaction between tested parameters were calculated.

\section{RESULTS AND DISCUSSION}

The antioxidant activity, and phenolic compounds as well as vitamin $\mathrm{C}$ content in fresh and processed cranberries were determined (Table 2). Fresh fruits were the richest source of vitamin $\mathrm{C}$ and polyphenols, both created their antioxidan activity. Freezing decreased the level of vitamin $\mathrm{C}$ by $25 \%$, whereas the phenolic compounds were not changed and antioxidant activity was surprisingly improved by $41 \%$. During convective drying, intensive losses of studied parameters were observed, especially when higher temperature was applied. The vitamin C level was strongly reduced by 62 and $87 \%$ during processing in 59 and $65^{\circ} \mathrm{C}$, respectively. Meanwhile the phenolic compouds losses amounted from 9 to $26 \%$, and antioxidant activity was reduced by $2-21 \%$. In comparison sweetened dried cranberries (commercial) contained significantly lower concentration of studied compounds, 5-fold, 3-fold and 3-fold lower for vitamin C, antioxidant activity and phenolic compounds, respectively.
Table 2 Content of bioactive compounds in tested samples (per $100 \mathrm{~g}$ dry weight)

\begin{tabular}{lccc}
\hline $\begin{array}{l}\text { Thermal } \\
\text { processing }\end{array}$ & $\begin{array}{c}\text { Vitamin C } \\
{[\mathrm{mg} / 100 \mathrm{~g} \mathrm{DW}]}\end{array}$ & $\begin{array}{c}\text { FRAP } \\
{[\mathrm{mmol} \mathrm{TE} / 100 \mathrm{~g}} \\
\mathrm{DW}]\end{array}$ & $\begin{array}{c}\text { Phenolic } \\
\text { compounds } \\
{[\mathrm{mg} \mathrm{GAE} / 100 \mathrm{~g}}\end{array}$ \\
\hline Fresh & $208.60 \pm 50.51$ & $101.30 \pm 0.27$ & $6434.94 \pm 78.86$ \\
Frozen & $156.03 \pm 2.67$ & $143.21 \pm 2.50$ & $6420.10 \pm 0.00$ \\
Dried I & $78.95 \pm 31.90$ & $98.88 \pm 5.37$ & $5847.58 \pm 105.15$ \\
Dried II & $26.32 \pm 0.00$ & $79.98 \pm 2.81$ & $4743.50 \pm 115.66$ \\
$\begin{array}{l}\text { Dried } \\
\text { sweetened }\end{array}$ & $41.36 \pm 5.32$ & $31.22 \pm 0.53$ & $2234.20 \pm 31.54$ \\
\hline
\end{tabular}

The obtained results confirmed negative impact of drying in high temperature on the levels of vitamin $\mathrm{C}$ in cranberry fruits and are in agreement with other authors findings. Del Caro et al. (2004), who studied the effects of drying parameters on two varieties of plums also showed detrimental impact of high temperature on the level of vitamin C. According to Świderski and Waszkiewicz-Robak (2005) losses of vitamin $\mathrm{C}$ as a result of the high temperature application are around $80 \%$. On the other hand, Pobereżny and Wszelaczyńska (2013) studied the effects of fixation methods on the quality of fruit and demonstrated that freezing is a good way to keep the high content of vitamin $\mathrm{C}$ in fruits.

The total phenolics content in studied fresh cranberry reached $865.5 \pm 10.6 \mathrm{mg}$ GAE / 100 g FW (6434.94 $\pm 78.86 \mathrm{mg}$ of GAE / $100 \mathrm{~g} \mathrm{DW})$ and slightly decreased during thermal processing. However, research conducted by Witkowska and Zujko (2009) showed significantly lower levels of polyphenols in Polish small cranberries (Oxycoccus palustris Pers.) fruits $(2440 \pm 321 \mathrm{mg}$ $100 \mathrm{~g} \mathrm{DW}$ ) in comparison to our results. Fabisiak et al. (2005) in the studies on the effect of the drying method and temperature on the level of polyphenols in apples have shown that drying at 60 and $70^{\circ} \mathrm{C}$ resulted in a $35 \%$ decrease in the polyphenolic compounds while drying at low temperatures, especially with the use of freeze-drying method, led to significantly lower losses of the tested compounds.

In studies conducted on Polish small cranberry by Witkowska and Zujko (2009), the antioxidant activity of cranberry fruits tested by FRAP method was on the lower level $(23.63 \pm 3,62 \mathrm{mmol}$ TE / $100 \mathrm{~g} \mathrm{DW})$ as compared to our findings. However, the confirmation of adverse effects of high temperature on antioxidant property of fruits were also obtained by Rutkowska et al. (2012). During studies on the level of bioactive compounds in wild rose fruits dried by a conventional and a freeze-dried methods they showed that the method of air chilling drying $\left(72^{\circ} \mathrm{C}\right)$ caused a greater decrease in bioactive compounds (lower $\%$ of DPPH radical inhibition) than in freeze-drying method (Rutkowska et al., 2012).

Total acidity of fresh and dried fruits were analyzed by titration (Figure 1). In order to compare the result, all values were calculated to the dry weight (DW), taking into account the water content of the fruit (approx. 87\%). The highest total acidity expressed as citric acid equivalent for fresh cranberry $(2.21 \mathrm{~g} / 100 \mathrm{~g}$ of $\mathrm{FW}=16.5 \mathrm{~g} / 100 \mathrm{~g} \mathrm{DW})$ was observed. The acidity of the fruit in the gentle drying $\left(59^{\circ} \mathrm{C}, 144 \mathrm{~h}\right)$ was reduced by $24.6 \%$. Dried sweetened cranberries contained the least amount of organic acids. The acidity of the different varieties of ripe American cranberry fruits identified in a study conducted by Teleszko (2011) was at the same level as in the presented study (2.18-2.66 g of citric acid / $100 \mathrm{~g} \mathrm{FW}$ ).

Freezing is one of the best ways of fusing fruit which is confirmed by the results of anthocyanin content (Figure 2). Fruit subjected to freezing have up to $4 \%$ more these compounds than fresh cranberries. This may indicate that even shortterm storage of fruits in the refrigerator caused small losses of such dye compounds, as compared to fruit preserved by freezing. The content of anthocyanins in dried fruits cranberries is about 54.3 to $90.3 \%$ lower than in fresh, the higher the drying temperature the more drastic decrease in the level of anthocyanins was observed. Anthocyanins are labile compounds that are not very resistant to the action of high temperatures. According to literature data, under the influence of heat glycosidic bonds in dye molecules undergo hydrolysis leading to unstable aglycones, which easily oxidize forming brown, high molecular weight compounds (Krucnar et al., 2014), who reported anthocyanin losses of $61 \%$ caused by $60 \mathrm{~s}$ heating at $115^{\circ} \mathrm{C}$ of highbush blueberries. The obtained results on the level of antocyanins in fresh cranberry fruits $(0.841 \mathrm{~g} / 100 \mathrm{~g}$ FW) indicated that the domestic fruits are more abundant source of these colored compounds as compared to Pappas and Schaich (2009) findings, who indicated the contents of anthocyanin in American cranberries at the level 0.013-0.171 mg / $100 \mathrm{~g}$ of FW. 


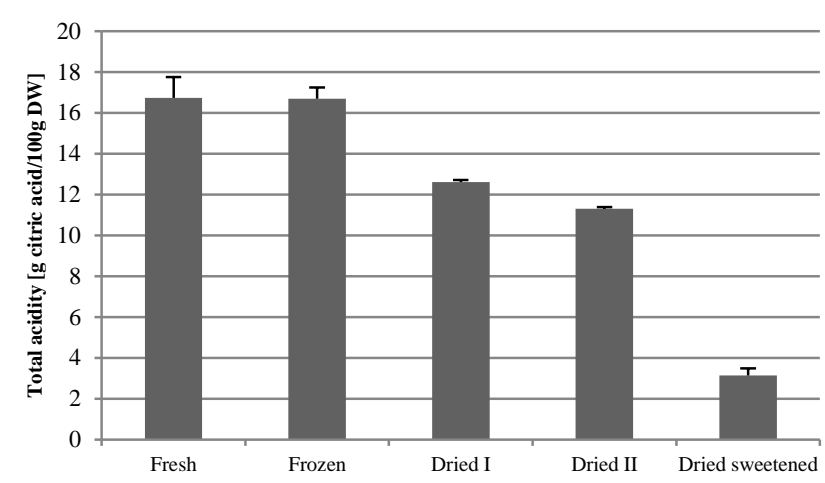

Figure 1 Total acidity of cranberry fruits ( $\mathrm{g}$ of citric acid/100 g DW) measured by titration

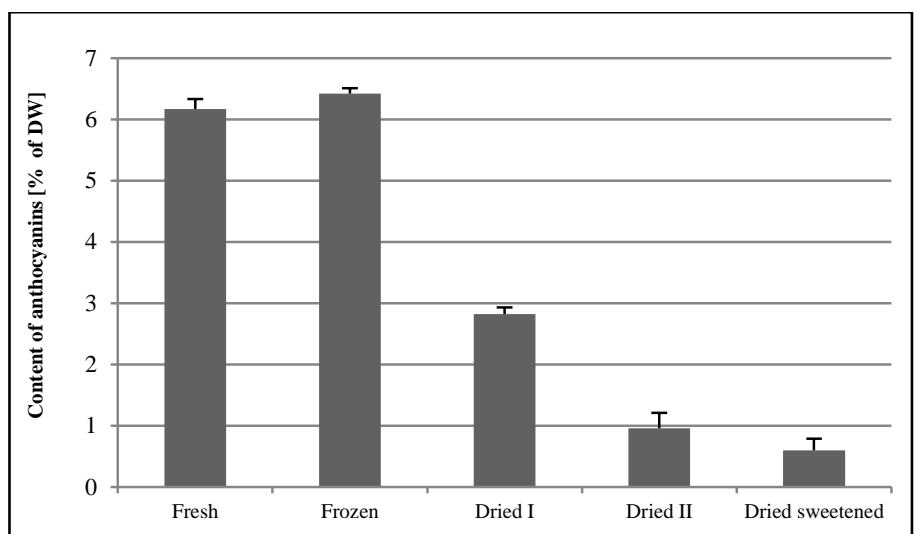

Figure 2 The content of anthocyanin in the cranberry fruits (expressed as cyanidin-3-glucoside)

The comparison of nutritional properties of experimentally processed cranberry fruits and commercial sweetened dried fruits showed that the conventionally dried products have better nutritional properties than commercial one, which was however less acidic. High calorific value of sweetened cranberries and lower level of bioactive compounds, caused that it is sweet snack, dangerous especially for persons with obesity problems.

Among studied parameters significant correlation was observed (Table 3). The total antioxidant activity was positively and significantly correlated with the content of phenolic compounds, anthocyanins and vitamin $\mathrm{C}$, indicating that those compounds are responsible for the antioxidant properties of cranberry fruits. The highest correlation $(\mathrm{r}=0.943)$ was observed for anthocyanins and vitamin C. It suggests that all tested compounds create antioxidant properties of cranberry fruits.

Table 3 The Pearson's correlation coefficient (r) between analyzed parameters

\begin{tabular}{|c|c|c|c|c|c|}
\hline & FRAP & $\begin{array}{l}\text { Phenolic } \\
\text { compounds }\end{array}$ & Acidity & Anthocyanins & $\begin{array}{c}\text { Vitamin } \\
\text { C }\end{array}$ \\
\hline FRAP & 1 & & & & \\
\hline $\begin{array}{l}\text { Phenolic } \\
\text { compouds }\end{array}$ & 0.922 & 1 & & & \\
\hline Acidity & 0.985 & 0.964 & 1 & & \\
\hline Anthocyanins & 0.824 & 0.833 & 0.943 & 1 & \\
\hline Vitamin C & 0.724 & 0.649 & 0.862 & 0.955 & 1 \\
\hline
\end{tabular}

\section{CONCLUSION}

Fresh cranberries contains large amounts of bioactive ingredients (vitamin C, polyphenols, anthocyanins), but their contents were reduced during drying process directly proportional to the applied temperature. The best method of cranberry fruits preservation is freezing which does not significantly change their chemical composition. Convective dried fruits possess greater nutritional value than commercial sweetened dried fruits, due to higher content of bioactive compounds as well as lower calorific value.

\section{REFERENCES}

AOAC OFFICIAL METHOD, 2005. Total Monomeric Anthocyanin Pigment Content of Fruit Juices, Beverages, Natural Colorants, and Wines. In: Official Methods of Analysis of AOAC International, 37, 37-39.

BLUMBERG, J. B., CAMESANO, T. A., CASSIDY, A., KRIS-ETHERTON, P., HOWELL, A., MANACH, C., OSTERTAG, L. M., SIES, H., SKULAS-RAY, A., VITA, J. A. 2013. Cranberries and their bioactive constituents in human health. Review. American Society for Nutrition, 4, 618-632, http://dx.doi:10.3945/an.113.004473.

CAILLET, S., CÔTÉ, J., DOYON, G., SYLVAIN, J. -F., LACROIX, M. 2011. Antioxidant and antiradical properties of cranberry juice and extracts. Food

Research International, 44 http://dx.doi:10.1016/j.foodres.2011.02.019.

ÇELIK, H., ÖZGEN, M., SERÇE, S., KAYA, C., 2008. Phytochemical accumulation and antioxidant capacity at four maturity stages of cranberry fruit. Scientia Horticulturae, 117, 345-348.

CÔTÉ, J., CAILlET, S., DOYON, G., DUSSAULT, D., SYLVAIN, J. -F., LACROIX, M. 2011. Antimicrobial effect of cranberry juice and extracts. Food Control, 22, 1413-1418, http://dx.doi:10.1016/j.foodcont.2011.02.024.

DEL CARO, A., PIGA, A., PINNA, I., FENU, P. M., AGABBIO, M., 2004 Effect of Drying Conditions and Storage Period on Polyphenolic Content, Antioxidant Capacity, and Ascorbic Acid of Prunes. Journal of Agricultural and Food Chemistry, 52, 4780-4784.

DOHADWALA, M.M., HOLBROOK, M., HAMBURG, N.M., SHENOUDA, S.M., CHUNG, W.B., TITAS, M., KLUGE, M.A., WANG, N., PALMISANO, J., MILBURY, P.E., BLUMBERG, J.B., VITA; J.A., 2011. Effects of cranberry juice consumption on vascular function in patients with coronary artery disease. The American Journal of Clinical Nutrition, 93, 934-940, doi 10.3945/ajen.110.004242.

DOROFEJEVA, K., RAKCEJEVA, T., GALOBURDA, R., DUKALSKA, L., KVIESIS, J., 2011. Vitamin C content in Latvian cranberries dried in convective and microwave vacuum driers. Procedia Food Science, 1, 433-440, http://dx.doi:10.1016/j.profoo.2011.09.067.

FABISIAK, A., SHENG, L., STAWCZYK, J., WITROWA-RAJCHERT, D., 2005. The influence of method and apples drying temperature

on the antioxidant activity of extracts produced from those dried apples Żywność. Nauka. Technologia. Jakość. 2, 318-327 (in Polish, abstract in English).

GRYSZCZYŃSKA, A. 2010. Żurawina amerykańska (Vaccinium macrocarpon) - lek na problemy urologiczne. Przegląd Urologiczny (www.przegladurologiczny.pl) (in Polish)

KANIEWSKA, J., GOZDECKA, G., DOMORADZKI, M., SZAMBOWSKA, A., 2013. Processing and characteristic of Kamchatka berries and their products Nauki Inżynierskie i Technologie/Engineering Sciences and Technologies, 4, 1, 58-67 (in Polish, abstract in English).

KUCNER, A., PAPIEWSKA, A., KLEWICKI, R., SÓJKA, M., KLEWICKA, E., 2014. Influence of thermal treatment on the stability

of phenolic compounds and the microbiological quality of sucrose solution following osmotic dehydration of highbush blueberry fruits. Acta Scientarum Polonorum, Technologia Alimentaria, 13, 1, 79-88

LACOMBE, A., WU, V. C. H., TYLER, S., EDWARDS, K.. 2010 Antimicrobial action of the American Canberry constituents; phenolics, anthocyanins and organic AIDS, against Escherichia coli O157:H7. International Journal of Food Microbiology, 139, 102-107, http://dx.doi:10.1016/j.ijfoodmicro.2010.01.035.

LAVIGNE, J.-P., BOURG, G., BOTTO, H., SOTTO, A. 2007. Cranberry (Vaccinium macrocarpon) et infections urinaires: étude et revue de la littérature. Pathologie Biologie, 55, 460-464, http://dx.doi:10.1016/j.patbio.2007.07.005.

MCKAY, D. L., BLUMBERG, J. B., 2007. Cranberries (Vaccinium macrocarpon) and cardiovascular disease risk factors. Nutrition Reviews, 65, 490-502, http://dx.doi.org/10.1111/j.1753-4887.2007.tb00273.x

MCKENNA, D.J., JONES, K., HUGHES, K., HUMPHREY, S., 2002. Botanical medicines. The desk reference for major herbal supplements. Second Edition. The Haworth Herbal Press, Inc., New York-London-Oxford.

PAPPAS, E., SCHAICH, K. M., 2009. Phytochemicals of Cranberries and Cranberry Products: Characterization, Potential Health Effects, and Processing Stability. Food Science and Nutrition, 49, 741-781, http://dx.10.1080/10408390802145377

PILJAC-ŽEGARAC, J., STIPČEVIĆ, T., BELŠČAL, A., 2009. Antioxidant properties and phenolic content of different floral origin honeys. Journal of ApiProduct and ApiMedical Science, 2, 43-50, http://dx.10.3896/IBRA.4.01.2.04 POBEREŻNY, J., WSZELACZYŃSKA, E., 2013. Wpływ metod konserwacji na wybrane cechy jakościowe owoców i warzyw znajdujących się $\mathrm{w}$ handlu detalicznym. Inżynieria i Aparatura Chemiczna, 52, 2, 92-94 (in Polish).

RUTKOWSKA, J., ADAMSKA, A., RUTKOWSKA, J., ADAMSKA, A., PIELAT, M., BIAŁEK, M. 2012. Comparison of composition and properties of Rosa rugosa fruits preserved using conventional and freeze-drying methods Żywność. Nauka. Technologia. Jakość. 4, 32-43 (in Polish, abstract in English). 
SEERAM, N.P., ADAMS, L.S., HARDY, M.L., HEBER, D., 2004. Total cranberry extract versus its phytochemical constituens: antiproliferative and synergistic effects against human tumor cell lines. Journal of Agriculture and Food Chemistry, 52, 9, 2512-2517, http://dx.10.1021/jf0352778

SUN, J., CHU, Y.F, WU, X., LIU, R.H., 2002. Antioxidant and antiproliferative activities of common fruits. Journal of Agriculture and Food Chemistry, 50, 25, 7449-7454, http://dx.10.1021/jf0207530

ŚWIDERSKI, F., WASZKIEWICZ-ROBAK, B., 2005. Składniki bioaktywne w żywności funkcjonalnej. Przemyst Spożywczy, 4, 20-22 (in Polish).

TELESZKO, M., 2011. American cranberry (Vaccinum macrocarpon L.) possibility of using it to produce bio-food. Żywność. Nauka. Technologia. Jakość 79, $132-141$ (in Polish, abstract in English).

WITKOWSKA, A., ZUJKO, M. E., 2009. Antioxidant activity of wild berries. Bromatologia $i$ Chemia Toksykologiczna, 3, 900-903 (in Polish, abstract in English). 